\title{
REMOVAL OF FLUORIDE FROM DRINKING WATER USING PROTONATED GLYCEROL DIGLYCIDYL ETHER CROSS-LINKED CHITOSAN BEADS
}

\author{
P.N.S. Pathirannehe ${ }^{1}$, T.D. Fernando ${ }^{1}$, C.S.K. Rajapakse ${ }^{1,}$
}

https://doi.org/10.23939/chcht15.02.205

\begin{abstract}
In this study, physically and chemically modified chitosan; protonated glycerol diglycidyl ether cross-linked chitosan beads $\left(\mathrm{GDCLCB} / \mathrm{H}^{+}\right)$were prepared and characterized using FTIR and SEM. The optimum defluoridation capacity (DC) of $\mathrm{GDCLCB} / \mathrm{H}^{+}$was observed at the initial $\mathrm{F}^{-}$ion concentration of $15 \mathrm{mg} / \mathrm{l}$, adsorbent dosage of $0.6 \mathrm{~g}$, contact time of $30 \mathrm{~min}$ and $\mathrm{pH}$ of the solution was in the range of 5-7 at $303 \pm 2 \mathrm{~K}$. The equilibrium adsorption data fitted well with Langmuir and Freundlich isotherm models. The maximum adsorption capacity $\left(q^{0}\right)$, obtained from Langmuir isotherm for $\mathrm{F}^{-}$ adsorption was found to be $2000 \mathrm{mg} / \mathrm{kg}$, which was significantly higher than that of unmodified chitosan $(192.3 \mathrm{mg} / \mathrm{kg})$ and most of the chitosan-based sorbents reported in the literature. Water samples collected from Medawachchiya, Sri Lanka, were treated with the adsorbents and the results suggested that GDCLCB/ $/ \mathrm{H}^{+}$could be used as an effective defluoridation agent.
\end{abstract}

Keywords: defluoridation capacity, fluoride, $\mathrm{GDCLCB} / \mathrm{H}^{+}$.

\section{Introduction}

Fluoride $\left(\mathrm{F}^{-}\right)$is one of the common anions mainly found in ground water. $\mathrm{F}^{-}$may enter water bodies due to the natural processes like weathering, volcanic activity, etc. and as an anthropogenic pollutant mainly by wastewater discharges from industries such as phosphate fertilizers (which contain an average of $3.8 \%$ fluorine), glass, aluminium production, ceramic, brick, iron works, and electroplating [1]. Fluoride can enter human body through water, food and industrial exposure and among them drinking water can be considered as the major source of daily intake of $\mathrm{F}^{-}$[2]. Depending on the total intake, $\mathrm{F}^{-}$is known to have both beneficial and adverse effects on humans, as summarized in Table 1.

Water fluoridation reduces tooth decay among adults and children but dental and skeletal fluorosis are also primarily associated with the consumption of

\footnotetext{
${ }^{1}$ Department of Chemistry, University of Kelaniya, Kelaniya, Sri Lanka shashikala@kln.ac.lk

(c) Pathirannehe PNS, Fernando TD, Rajapakse CSK, 2021
}

drinking water containing elevated levels of $\mathrm{F}^{-}$[3]. Therefore, a guideline value of $1.5 \mathrm{mg} / 1$ of $\mathrm{F}^{-}$was recommended by World Health Organization (WHO) as the maximum permissible concentration level of $\mathrm{F}^{-}$in drinking water [4]. Various treatment methods including ion exchange [5], chemical precipitation, coagulation [6, 7]. adsorption [8, 10], reverse osmosis [9], nano-filtration [10], electrodialysis [11], etc. have been widely used for the treatment of $\mathrm{F}^{-}$containing water. Among these methods, $\mathrm{F}^{-}$removal by adsorption is the most widely used method because most other processes have significant drawbacks such as high maintenance cost, incomplete removal, high-energy requirements, generation of toxic sludge, etc. [12]. A wide variety of adsorbents and their modifications have been tested for the $\mathrm{F}^{-}$removal from water. These include activated carbons [13], activated alumina [14], bauxite [15], hematite [16], polymeric resins [17], activated rice husk [18], brick powder [19], pumice stone [20], red soil, charcoal, brick, fly ash, serpentine [21], seed extracts of Moringaoleifera [22], granular ceramics [23], chitin [16], modified ferric oxide/hydroxide, hydroxyapatite [24], zirconium and cerium modified materials [25], chitosan derivatives and composites [16, 26], etc. As bisorption is considered to be a cost-effective, environmentally friendly, simple and efficient method for water treatment, in this study the potential of use of physically and chemically modified chitosan as $\mathrm{F}^{-}$removal agent in drinking water was studied.

Chitosan, deacetylated product of chitin, is widely distributed in nature. Being a biopolymer, it is biodegradable, eco-friendly, and non-toxic. It is made up of D-glucosamine $(\mathrm{GlcN})$ and $N$-acetyl-D-glucosamine (GlcNac) which are linked by $\beta$-(1,4)-glycosidic bonds. The structure of chitosan is depicted in Fig. 1.

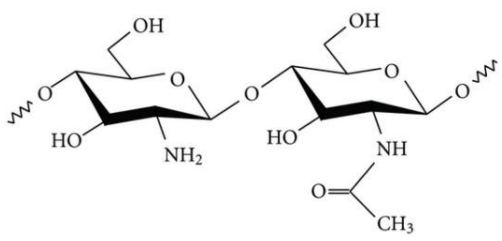

Fig. 1. The structure of chitosan (the degree of deacetylation of chitosan used in the study was $85 \%$ ) 
Health effects of fluoride [1]

\begin{tabular}{|c|l|}
\hline Concentration of fluoride, $\mathrm{mg} / \mathrm{l}$ & \multicolumn{1}{|c|}{ Health effects } \\
\hline Nil & Limited growth and fertility \\
\hline $0.0-0.5$ & Dental caries \\
\hline $0.5-1.5$ & Promotes dental health resulting in healthy teeth; prevents tooth decay \\
\hline $1.5-4.0$ & Dental fluorosis (mottling of teeth) \\
\hline $4.0-10.0$ & Dental fluorosis, skeletal fluorosis \\
\hline$>10.0$ & Crippling fluorosis \\
\hline
\end{tabular}

Although several studies on use of chitosan as a water purification agent for the removal of different pollutants [14, 27-33] have been published, only a few studies reported on its potential to remove $\mathrm{F}^{-}$from drinking water [34-37]. As chitosan itself is less stable and has a poor $\mathrm{F}^{-}$adsorption capacity, the objectives of this study were to prepare physically and chemically modified chitosan; protonated glycerol diglycidyl ether cross-linked chitosan beads $\left(\mathrm{GDCLCB} / \mathrm{H}^{+}\right)$to enhance the stability of chitosan and consequently to enhance its potential for attracting $\mathrm{F}^{-}$ions by protonating the polymer and evaluation of its defluoridation capacity (DC) under different experimental conditions (initial $\mathrm{F}^{-}$concentration, adsorbent dosage, contact time and $\mathrm{pH})$ at room temperature $(303 \pm 2 \mathrm{~K})$.

\section{Experimental}

\subsection{Preparation of Glycerol Diglycidyl Ether Cross-linked Chitosan Beads (GDCLCB)}

Chitosan $(2 \% \mathrm{w} / \mathrm{v})$ solution was prepared in acetic acid $(2.0 \% \mathrm{v} / \mathrm{v})$. Uniform sized chitosan beads were formed when this chitosan solution was dropped in to a $\mathrm{NaOH}(0.50 \mathrm{M})$ bath using a syringe $(10.0 \mathrm{ml})$. The beads were soaked in $\mathrm{NaOH}$ solution for $24 \mathrm{~h}$ and then the wet chitosan beads were rinsed with distilled water to adjust the $\mathrm{pH}$ to 7 . The wet chitosan beads were cross-linked by soaking the beads in glycerol diglycidyl ether for $48 \mathrm{~h}$ to form glycerol diglycidyl ether cross-linked chitosan beads (GDCLCB) and then cross-linked beads were washed with deionized water to remove any excess glycerol diglycidyl ether [37]. Then the beads were air dried until they gain a constant weight.

\subsection{Preparation of Protonated Glycerol Diglycidyl Ether Cross-linked Chitosan Beads (GDCLCB/ $\mathrm{H}^{+}$)}

In order to facilitate $\mathrm{F}^{-}$adsorption, cross-linked chitosan beads were protonated by treating it with concentrated $\mathrm{HCl}$ for 30 min to yield protonated glycerol diglycidyl ether cross-linked chitosan beads $\left(\mathrm{GDCLCB} / \mathrm{H}^{+}\right)$[37]. Protonated beads were washed with deionized water to adjust the $\mathrm{pH}$ to 7 and air dried and used for further studies.

\subsection{Characterization of the Adsorbent}

Surface morphology of unmodified chitosan, modified chitosan; GDCLCB $/ \mathrm{H}^{+}$and $\mathrm{F}^{-}$adsorbed GDCLCB $/ \mathrm{H}^{+}$were examined by scanning electron microscopy (VEGA3 SEM, TESCAN). Fourier transformation infrared (FTIR) spectra of chitosan, GDCLCB/ $\mathrm{H}^{+}$ and $\mathrm{F}^{-}$adsorbed GDCLCB/ $\mathrm{H}^{+}$were obtained by FTIR spectroscopy (ALPHA-T, Bruker, Germany) using attenuated total reflection (ATR) method.

\subsection{Preparation of Adsorbate Solution}

Fluoride standard solution (C) 1996 Orian Research, $100.0 \pm 0.5 \mathrm{mg} / \mathrm{l}$ ) was used as the stock solution and it was diluted using deionized water to the required concentrations for the batch experiments and isotherm studies.

\subsection{Batch Adsorption Studies}

Batch experiments were conducted in duplicate to investigate the effect of initial $\mathrm{F}^{-}$concentration, adsorbent dosage, contact time and $\mathrm{pH}$ of the medium for the fluoride adsorption onto GDCLCB/ $\mathrm{H}^{+}$. To study the effect of initial adsorbate concentration on $\mathrm{F}^{-}$adsorption, fluoride solution $(5,10,15,20$ and $30 \mathrm{ml})$ was introduced separately into polypropylene containers having $\mathrm{GCLCB} / \mathrm{H}^{+}(0.5 \mathrm{~g})$. Samples were shaken at room temperature $(303 \pm 2 \mathrm{~K})$ for $30 \mathrm{~min}$ in $10 \mathrm{~min}$ intervals. After $30 \mathrm{~min}$, all the samples were filtered using filter papers (Whatman: 1, $42.5 \mathrm{~mm}$ diameter). Total Ionic Strength Adjustment Buffer III (TISAB III) was added to the filtrate at volume ratio of $1: 3$ and the concentration of fluoride in filtrates was detected by fluoride ion selective electrode (EUTECH 510. $\mathrm{pH} / \mathrm{mV} /{ }^{\circ} \mathrm{C}$ meter Cyberscan). Results were recorded as the defluoridation capacity (DC) using the Eq. (1). 


$$
D C=\frac{\left(C_{0}-C_{e}\right) \cdot V}{W}
$$

where $D C$ is the defluoridation capacity of adsorbent, $\mathrm{mg} / \mathrm{kg} ; C_{0}$ and $C_{e}$ are initial and final concentration of $\mathrm{F}^{-}$, respectively, $\mathrm{mg} / \mathrm{l} ; W$ is the dry weight of absorbent, $\mathrm{kg} ; V$ is the volume of the solution, 1 .

The effect of adsorbent dosage was studied by varying the $\mathrm{GDCLCB} / \mathrm{H}^{+}$dosage $(0.2,0.4,0.6,0.8$ and $1.0 \mathrm{~g})$ and the effect of contact time on the adsorption of $\mathrm{F}^{-}$onto $\mathrm{GDCLCB} / \mathrm{H}^{+}$was also determined by varying the contact time ( $30 \mathrm{~min}, 1 \mathrm{~h}, 1.5 \mathrm{~h}$ and $2 \mathrm{~h}$ ) using $30.0 \mathrm{ml}$ of $15 \mathrm{mg} / \mathrm{l} \mathrm{F}$ solutions as the test solutions at room temperature $(303 \pm 2 \mathrm{~K})$. Initial $\mathrm{pH}$ of the solutions was adjusted to $\mathrm{pH}$ values of $3,5,7$, and 9 using $0.1 \mathrm{M} \mathrm{HCl}$ and $\mathrm{NaOH}$ solutions as required to investigate the effect of $\mathrm{pH}$ of the solution on $\mathrm{F}^{-}$adsorption onto GDCLCB $/ \mathrm{H}^{+}$. Results were recorded as percent of $\mathrm{F}^{-}$removal $\left(\% \mathrm{~F}^{-}\right.$ removal) which was calculated using the Eq. (2).

$$
\% F^{-} \text {removal }=\frac{C_{0}-C_{e}}{C_{0}} \cdot 100
$$

\subsection{Adsorption Isotherm Studies}

$\mathrm{GDCLCB} / \mathrm{H}^{+}(0.6 \mathrm{~g})$ was placed in separate polypropylene bottles with different fluoride solution concentrations $(3,5,10,15$ and $20 \mathrm{mg} / 1$ in $30.0 \mathrm{ml})$ and kept for $30 \mathrm{~min}$, and stirred with $10 \mathrm{~min}$ intervals at room temperature $(303 \pm 2 \mathrm{~K})$. Solutions were filtered and potentials of the filtrates were recorded after adding TISAB III buffer. The defluoridation capacities were calculated and the equilibrium data were tested with Langmuir and Freundlich adsorption isotherm models to investigate the adsorption characteristics of the adsorbent. Adsorption isotherm studies were repeated with chitosan flakes in order to compare the adsorption characteristics of modified chitosan, GDCLCB $/ \mathrm{H}^{+}$with that of unmodified chitosan.

\subsection{Field Studies}

Seventeen water samples were randomly collected from dug wells, wells, reverse osmosis water treatment plants, and reservoirs of two homestead sites in Medawachchiya, North Central Province (NCP) of Sri Lanka during August 2017. Basic water quality parameters of the collected samples were determined using the standard methods ( $\mathrm{pH}$, electrical conductivity, total dissolved solids (TDS); by multi-parameter analyser, dissolved oxygen (DO); by DO meter, hardness by EDTA titration and alkalinity by acid base titration). $\mathrm{F}^{-}$ concentration of each water sample was measured using fluoride ion selective electrode. In order to find the applicability of the GDCLCB/ $\mathrm{H}^{+}$under field conditions, each filtered water sample $(30.0 \mathrm{ml})$ was treated with $\mathrm{GDCLCB} / \mathrm{H}^{+}(0.6 \mathrm{~g})$ for $30 \mathrm{~min}$ shaking with $10 \mathrm{~min}$ intervals. Then the solution was filtered with a filter paper (Whatman: 1, $42.5 \mathrm{~mm}$ diameter) and TISAB III (10.0 ml) was added to the filtrate and the remaining fluoride concentration was determined and the results were reported as mean \pm standard deviation.

\section{Results and Discussion}

\subsection{Preparation of Protonated Glycerol Diglycidyl Ether Cross-linked Chitosan Beads (GDCLCB/ $\mathrm{H}^{+}$)}

In this study, chitosan flakes were first physically modified to chitosan beads (CB) to enhance the surface area of the adsorbent. $\mathrm{CB}$ were circular in shape with the average diameter of $1.09 \pm 0.02 \mathrm{~mm}$. GDCLCB were prepared by chemical modification of chitosan by using glycerol diglycidylether (Fig. 2) as the cross-linking agent to improve its stability as well as its $\mathrm{F}^{-}$adsorption capacity. GDCLCB was then treated with conc. $\mathrm{HCl}$ in order to utilize the amine groups in chitosan for $\mathrm{F}^{-}$binding by protonating them $\left(-\mathrm{NH}_{3}{ }^{+}\right)$to give the polymer a cationic behaviour and consequently to enhance the potential for attracting $\mathrm{F}^{-}$. Unmodified chitosan flakes and modified chitosan, GDCLCB/ $\mathrm{H}^{+}$are shown in Fig. 3 and the proposed structures for GDCLCB and GDCLCB $/ \mathrm{H}^{+}$ are depicted in Fig. 4.

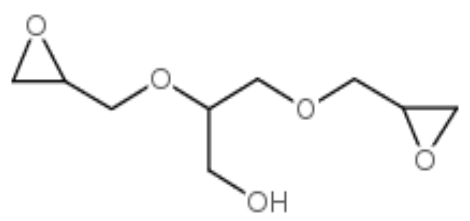

Fig. 2. The structure of the cross-linking agent; glycerol diglycidyl ether

\subsection{Characterization of the Adsorbent by SEM and FTIR}

The surface morphology of the adsorbents was examined by SEM. SEM micrographs of unmodified chitosan (chitosan flakes) and physically and chemically modified chitosan, GDCLCB $/ \mathrm{H}^{+}$before and after $\mathrm{F}^{-}$ adsorption are shown in Fig. 5 and Fig. 6, respectively.

Compared to the surface of unmodified chitosan, GDCLCB $/ \mathrm{H}^{+}$has a highly microporous structure with irregular surface indicating the increased surface area upon modification (Fig. 5). As depicted in Fig. 6, the $\mathrm{F}^{-}$ adsorbed chitosan derivatives have less porous structure with smooth surface compared to $\mathrm{F}^{-}$unadsorbed chitosan derivative due to adsorbed $\mathrm{F}^{-}$ions filling the pores that existed before the adsorption. 


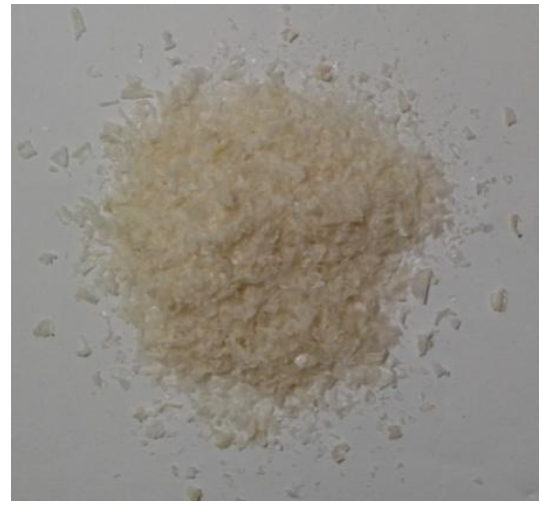

a)

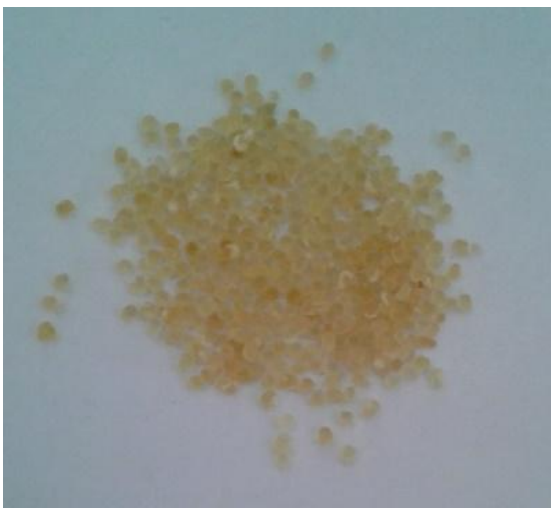

b)

Fig. 3. Unmodified chitosan flakes (a); physically and chemically modified chitosan, GDCLCB/ $\mathrm{H}^{+}$(b)

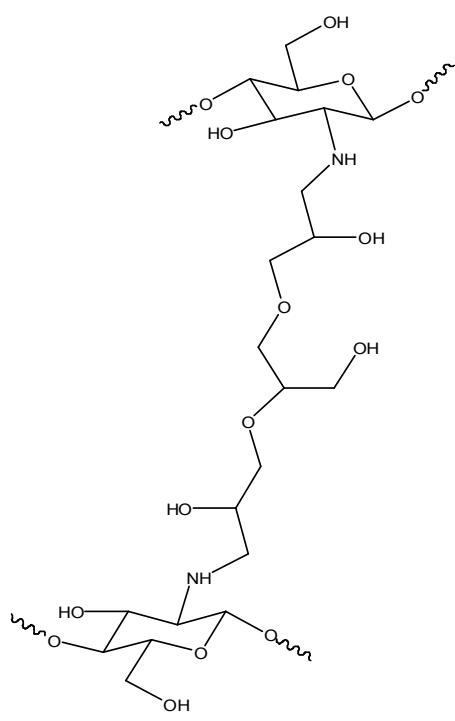

a)

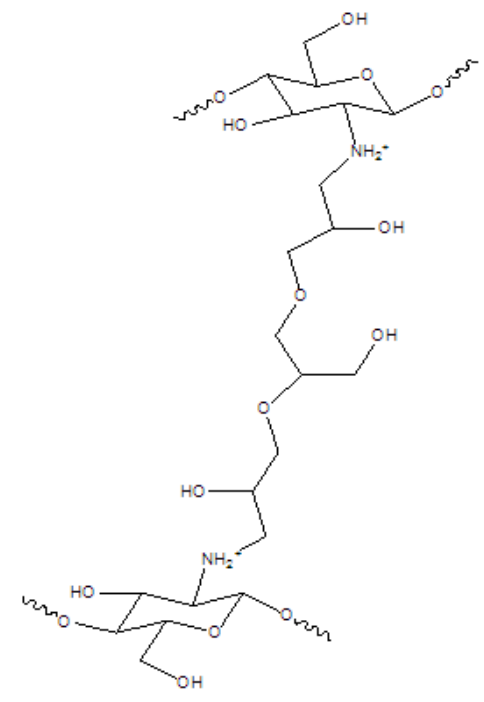

b)

Fig. 4. Proposed structures for GDCLCB (a) and GDCLCB/ $\mathrm{H}^{+}$(b)

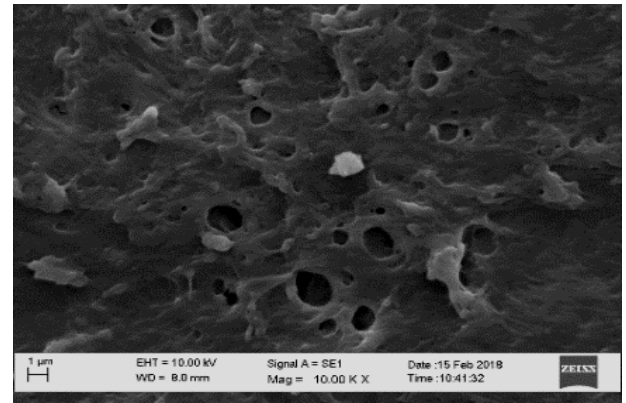

a)

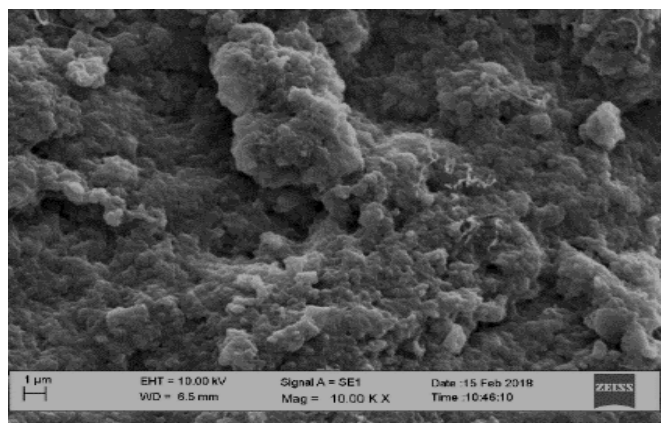

b)

Fig. 5. SEM micrographs of unmodified chitosan flakes (a) and $\mathrm{GDCLCB} / \mathrm{H}^{+}$(b). Magnification is $10.00 \mathrm{kx}$ 


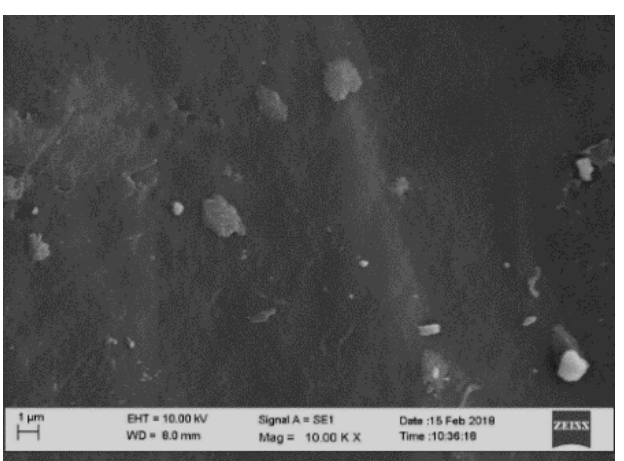

a)

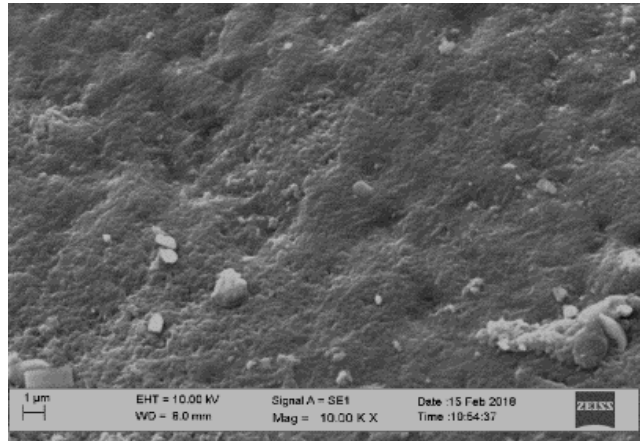

b)

Fig. 6. SEM micrographs of fluoride adsorbed unmodified chitosan flakes (a) and fluoride adsorbed GDCLCB/H ${ }^{+}$(b). Magnification is $10.00 \mathrm{kx}$

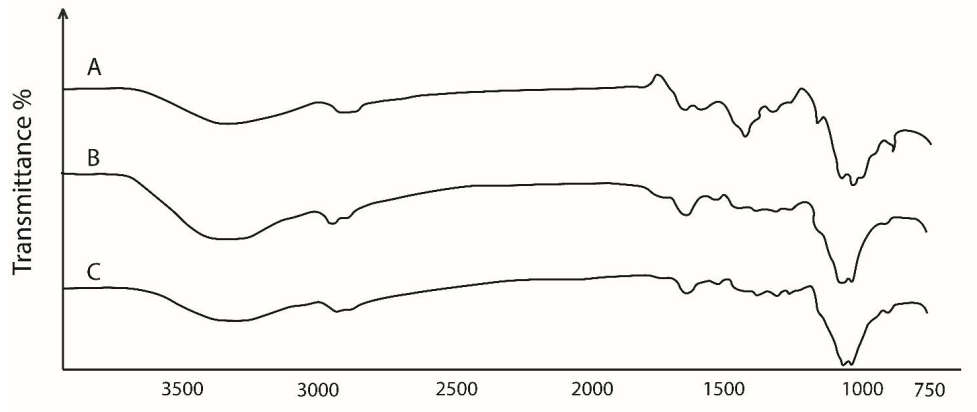

Fig. 7. FTIR spectra of chitosan (a), GDCLCB/ $\mathrm{H}^{+}$(b) and $\mathrm{F}^{-}$adsorbed GDCLCB/ $\mathrm{H}^{+}$(c)

FTIR spectroscopy also used to characterize the adsorbent as FTIR is an important analysis tool to assess functional groups in a chemical compound. Fig. 7 depicts the FTIR spectra of chitosan (a), GDCLCB/ $\mathrm{H}^{+}$(b) and $\mathrm{F}^{-}$ adsorbed GDCLCB/H $\mathrm{H}^{+}$(c) in the $750-4000 \mathrm{~cm}^{-1}$ wavenumber range.

The main bands of IR spectrum of chitosan include a strong broad band at the wavenumber region 3250 $3400 \mathrm{~cm}^{-1}$, which corresponds to $\mathrm{N}-\mathrm{H}$ and $\mathrm{O}-\mathrm{H}$ stretching vibrations and intra-molecular hydrogen bonds [37]. The bands appearing at around 2885 and $2852 \mathrm{~cm}^{-1}$ correspond to $\mathrm{C}-\mathrm{H}$ symmetric stretching and $\mathrm{C}-\mathrm{H}$ asymmetric stretching, respectively. Bands at around 1629 and $1573 \mathrm{~cm}^{-1}$ can be attributed to the $\mathrm{C}=\mathrm{O}$ stretching of $\mathrm{N}$-acetyl groups [38] and $\mathrm{N}-\mathrm{H}$ bending vibration of the primary amine [39]. As shown in Fig. 7b, after modification of chitosan to form GDCLCB/ $\mathrm{H}^{+}$, the IR bands originally appeared at around $3271 \mathrm{~cm}^{-1}$ attributed to $-\mathrm{OH}$ and $-\mathrm{NH}_{2}$ stretching vibrations was shifted to lower wave number of $3253 \mathrm{~cm}^{-1}$ indicating that the crosslinking by glycerol diglycidyl ether affects the normal vibration scheme of chitosan. The peak was also broadened due to the protonation of cross-linked chitosan beads. The IR band which appeared at around $1573 \mathrm{~cm}^{-1}$ corresponding to bending vibration of $\mathrm{NH}_{2}$ was not observed in IR spectrum of GDCLCB $/ \mathrm{H}^{+}$and this may be shifted and overlapped by other bands. Similar results were observed in another research [40]. As shown in Fig. $7 \mathrm{c}$, upon binding of $\mathrm{F}^{-}$, mainly the bands in IR spectrum of GDCLCB $/ \mathrm{H}^{+}$, which correspond to $-\mathrm{OH}$ and $-\mathrm{NH}_{2}$ stretching vibrations were slightly broadened and getting shifted to a higher frequency suggesting that there may be interactions probably through electrostatic attractions between $\mathrm{F}^{-}$ions and the protonated functional groups ($\mathrm{NH}_{3}{ }^{+}$) in GDCLCB/ $\mathrm{H}^{+}$as it has already been known that upon binding of sorbate with sorbent, the IR of the bonds (IR bands) in the close vicinity of the coordination site of sorbent will be significantly shifted when compared with sorbate-free sorbent. The sorbate binding affects the normal vibration scheme of sorbent due to the formation of new sorbent-sorbate bond [41].

\subsection{Batch Adsorption Studies}

\subsubsection{Effect of initial $\mathrm{F}^{-}$concentration}

As shown in Fig. 8, the DC of GDCLCB/ $\mathrm{H}^{+}$ gradually increased as the initial $\mathrm{F}^{-}$concentration increased. Similar observation was reported for $\mathrm{F}^{-}$removal by Viswanathan and Meenakshi [42]. The highest DC was observed with $15 \mathrm{mg} / \mathrm{l}$ initial concentration of $\mathrm{F}^{-}$. 


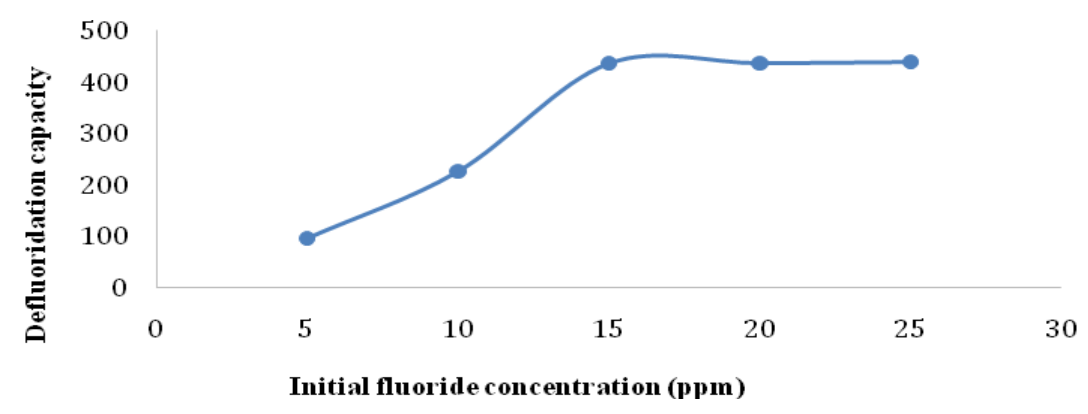

Fig. 8. Effect of initial $\mathrm{F}^{-}$concentration on $\mathrm{DC}$ of GDCLCB/ $\mathrm{H}^{+}$ (adsorbent dose is $0.5 \mathrm{~g}$, contact time is $30 \mathrm{~min}$, temperature is $303 \pm 2 \mathrm{~K}$ )

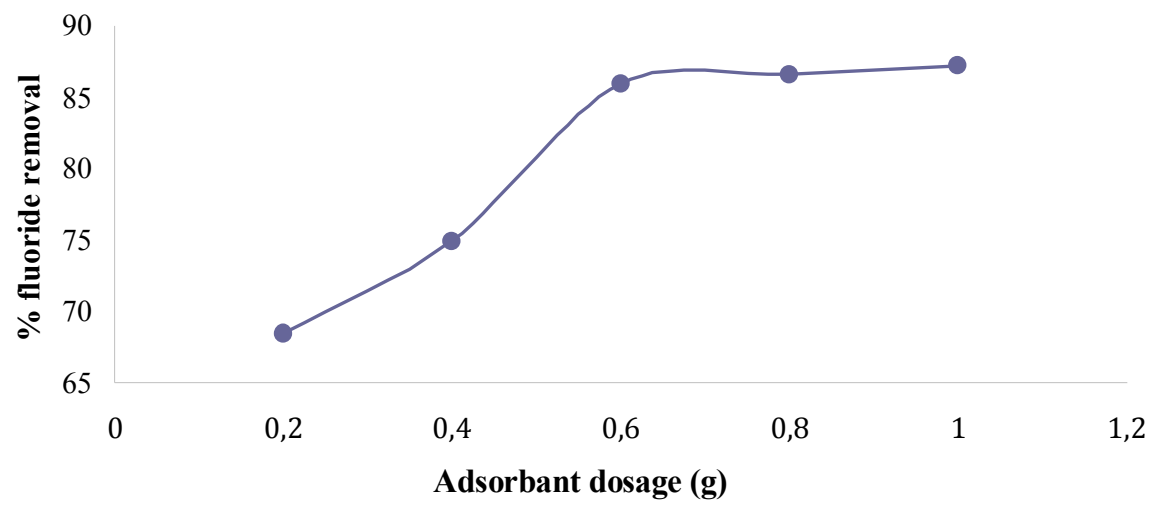

Fig. 9. The $\% \mathrm{~F}^{-}$removal by the adsorbent at different adsorbent dosages of GCLCB $/ \mathrm{H}^{+}$ (initial $\mathrm{F}^{-}$concentration is $15 \mathrm{mg} / \mathrm{l}(30 \mathrm{ml})$, temperature is $303 \pm 2 \mathrm{~K}$, contact time is $30 \mathrm{~min}, \mathrm{pH}$ is 7 )

\subsubsection{The effect of adsorbent dosage}

Fig. 9 shows the relationship between the adsorbent dosage and the percentage $\mathrm{F}^{-}$removal by GDCLCB $/ \mathrm{H}^{+}$.

With the increase of adsorbent dosage from 0.2 to $1.0 \mathrm{~g}$, percentage of fluoride removal increases gradually up to $82.6 \%$ due to the increase in the number of adsorption sites as the dose of the adsorbent increases. As shown in Fig. 9, maximum $\mathrm{F}^{-}$removal was observed when the adsorbent dosage was at around $0.6 \mathrm{~g}$. Further increase in adsorbent dose results in a negligible change in percent of $\mathrm{F}^{-}$removal. Therefore, $0.6 \mathrm{~g}$ of adsorbent dosage was selected as the optimum dosage for further batch adsorption studies.

\subsubsection{The effect of contact time}

The effect of contact time on $\mathrm{F}^{-}$removal by the adsorbent is graphically depicted in Fig. 10. The $\mathrm{F}^{-}$ removal \% was increased when contact time was increased from 10 to $30 \mathrm{~min}$ and the system attained equilibrium within $30 \mathrm{~min}$ as the adsorbent got saturated. Therefore, contact time of $30 \mathrm{~min}$ was chosen to conduct isotherm experiments.

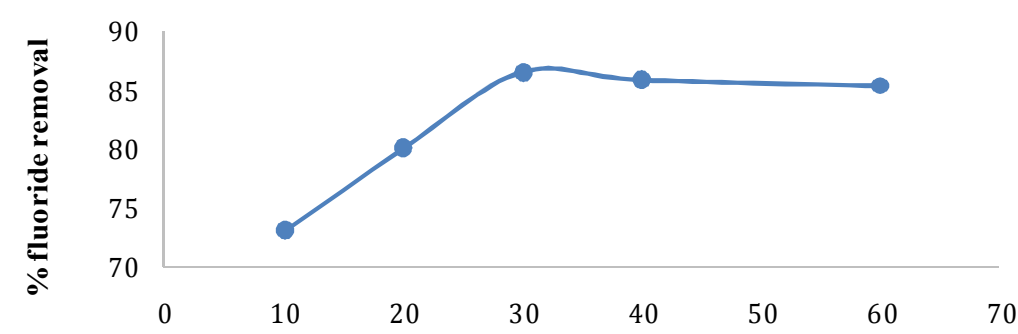

Time (Min)

Fig. 10. Effect of contact time on \% removal of $\mathrm{F}^{-}$by the adsorbent GCLCB $/ \mathrm{H}^{+}$ (initial $\mathrm{F}^{-}$concentration is $15 \mathrm{mg} / \mathrm{l}(30 \mathrm{ml})$, temperature is $303 \pm 2 \mathrm{~K}$, adsorbent dosage is $0.6 \mathrm{~g}$, $\mathrm{pH}$ is 7 ) 


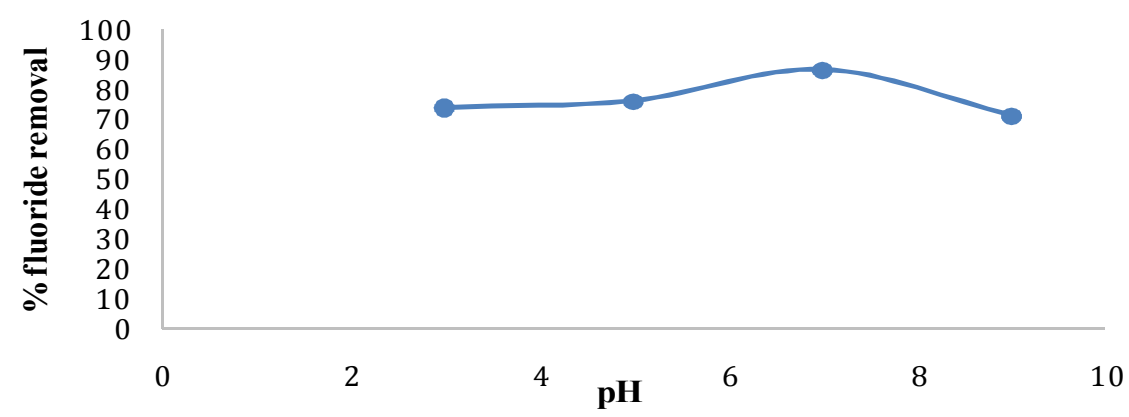

Fig. 11. Effect of $\mathrm{pH}$ of the medium on $\%$ removal of $\mathrm{F}^{-}$by the adsorbent GCLCB/ $\mathrm{H}^{+}$

(initial $\mathrm{F}^{-}$concentration is $15 \mathrm{mg} / \mathrm{l}(30 \mathrm{ml})$, temperature is $303 \pm 2 \mathrm{~K}$, adsorbent dosage is $0.6 \mathrm{~g}$, contact time is $30 \mathrm{~min}$ )

\subsubsection{Effect of $\mathrm{pH}$ of the solution}

The $\%$ of $\mathrm{F}^{-}$removal of $\mathrm{GCLCB} / \mathrm{H}^{+}$at different $\mathrm{pH}$ values is presented in Fig. 11. According to the results, the $\mathrm{F}^{-}$ions were effectively removed by the adsorbent at $\mathrm{pH}$ range of 5-7 and $\mathrm{F}^{-}$removal \% was reduced in highly acidic and alkaline media. As most of the collected water samples were at neutral $\mathrm{pH}$, further studies were conducted in neutral $\mathrm{pH}$.

The results revealed that the DC of GDCLCB/ $\mathrm{H}^{+}$ under optimized conditions (adsorbent dosage $0.6 \mathrm{~g}$, initial $\mathrm{F}^{-}$concentration $15 \mathrm{mg} / \mathrm{l}$, contact time $30 \mathrm{~min}$, temperature $303 \pm 2 \mathrm{~K}$ ) was $655.37 \mathrm{mg} / \mathrm{kg}$.

\subsection{Adsorption Isotherm Studies}

As the adsorption isotherms are the most common way of describing adsorption characteristics of an adsorbent in this study two common isotherm models, namely Langmuir and Freundlich adsorption isotherms were used to test the equilibrium relationships between the adsorbent, GCLCB $/ \mathrm{H}^{+}$and the adsorbate, $\mathrm{F}^{-}$. Langmuir model proposed by Irving Langmuir in 1916, assumes ideal solutions, homogeneous and independent monolayer adsorption [43]. The linear form of the Langmuir equation is expressed by the Eq. (3).

$$
\frac{C}{q_{e}}=\frac{1}{b q_{0}}+\frac{C}{q_{0}}
$$

where $q_{e}$ is the amount of adsorbate adsorbed per unit weight of adsorbent at equilibrium, $\mathrm{mg} / \mathrm{kg} ; C$ is the equilibrium concentration of adsorbate, $b$ is adsorption coefficient related to the surface energy, $1 / \mathrm{mg} ; q_{\mathrm{o}}$ is the amount of adsorbate adsorbed per unit weight of adsorbent corresponding to complete coverage of available sites, $\mathrm{mg} / \mathrm{kg}$.

Freundlich adsorption isotherm, an empirical model, can be applied to multilayer adsorption, over a heterogeneous surface [44]. The linear form of Freundlich isotherm is given as

$$
\log q_{e}=\frac{1}{n} \log C+\log k
$$

where $q_{e}$ is the amount of solute adsorbed per unit weight of adsorbent at equilibrium, $C$ is the equilibrium concentration of adsorbate, and Freundlich isotherm constants $k$ and $n$ are related to adsorption capacity and intensity of adsorption, respectively [44]. The plots of Langmuir and Freundlich adsorption isotherms are shown in Figs. 12 and 13, respectively, and Table 2 summarizes the Langmuir and Freundlich isotherm parameters for the $\mathrm{F}^{-}$adsorption onto chitosan flakes and $\mathrm{GCLCB} / \mathrm{H}^{+}$.

As shown in Figs. 12a and 13a, equilibrium data obtained from the study of adsorption of $\mathrm{F}^{-}$onto unmodified chitosan was fitted to Freundlich isotherm better than the Langmuir isotherm with high correlation coefficient $\left(R^{2}\right)$ whereas the equilibrium data obtained for modified chitosan, GDCLCB $/ \mathrm{H}^{+}$was well fitted with both Langmuir and Freundlich isotherm models with high correlation coefficients $\left(R^{2}\right.$ of Langmuir isotherm is $0.9872, R^{2}$ of Freundlich isotherm is 0.9991$)$ as depicted in Figs. $12 \mathrm{~b}$ and 13b. Freundlich isotherm constants $1 / n$, for two adsorbents used in the experiment (chitosan flakes and $\mathrm{GDCLCB} / \mathrm{H}^{+}$) are 0.932 and 0.891 , respectively. Since the values of $1 / n$ are less than 1 for both adsorbents, it indicates that the adsorption process is favourable for the adsorbents under the given experimental conditions [44]. As summarized in Table 2, Langmuir isotherm constant of $\mathrm{GDCLCB} / \mathrm{H}^{+} \quad\left(q_{0}=2000 \mathrm{mg} / \mathrm{kg}\right)$ is higher than that of unmodified chitosan $\left(q_{0}=192.3 \mathrm{mg} / \mathrm{kg}\right)$. The results clearly lead to the conclusion that the physical and chemical modification has enhanced the surface area and the $\mathrm{F}^{-}$adsorption potential of chitosan. $q_{0}$ values reported for the adsorption of $\mathrm{F}^{-}$onto different chitosan-based adsorbents recorded in the literature are given is Table 3 and according to that, $q_{0}$ obtained for $\mathrm{GDCLCB} / \mathrm{H}^{+}$is a significantly higher value than that for most of the other sorbents reported previously. 
Parameter values of Langmuir and Freundlich adsorption isotherms $(T=303 \pm 2 \mathrm{~K})$

\begin{tabular}{|c|c|c|c|c|c|c|c|}
\hline \multirow{2}{*}{ Type of adsorbent } & \multicolumn{3}{|c|}{ Langmuir constants } & \multicolumn{3}{|c|}{ Freundlich constants } \\
\cline { 2 - 8 } & $\mathrm{q}_{0}, \mathrm{mg} / \mathrm{kg}$ & $b, 1 / \mathrm{kg}$ & $R^{2}$ & $k,(\mathrm{mg} / \mathrm{kg})(1 / \mathrm{mg})^{1 / \mathrm{n}}$ & $n$ & $1 / n$ & $R^{2}$ \\
\hline Chitosan flakes & 192.3 & 0.018 & 0.9376 & 3.566 & 1.073 & 0.932 & 0.9963 \\
\hline GDCLCB/H & 2000 & 0.017 & 0.9872 & 36.90 & 1.123 & 0.891 & 0.9991 \\
\hline
\end{tabular}

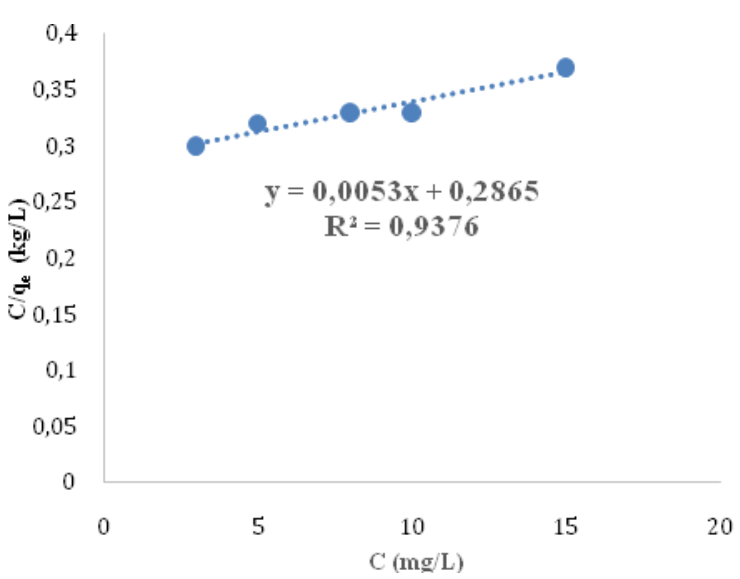

a)

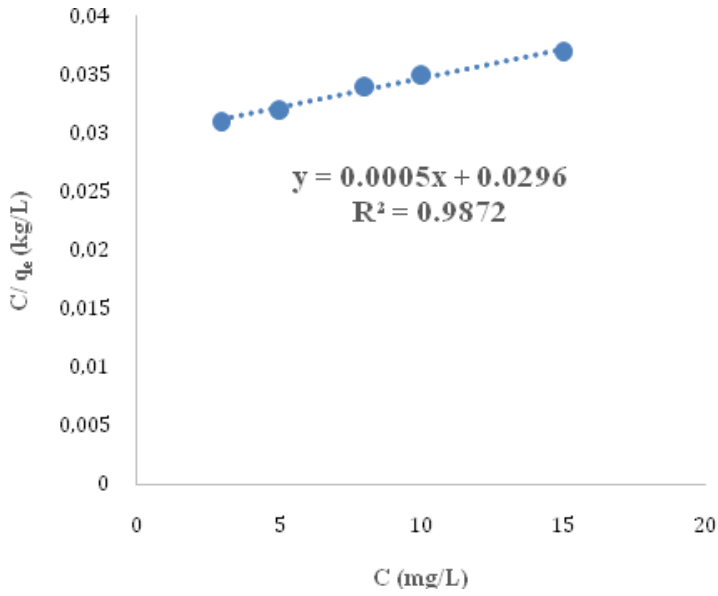

b)

Fig. 3. Langmuir adsorption isotherm for the $\mathrm{F}^{-}$ adsorption onto chitosan flakes(a) and $\mathrm{GDCLCB} / \mathrm{H}^{+}(\mathrm{b})$

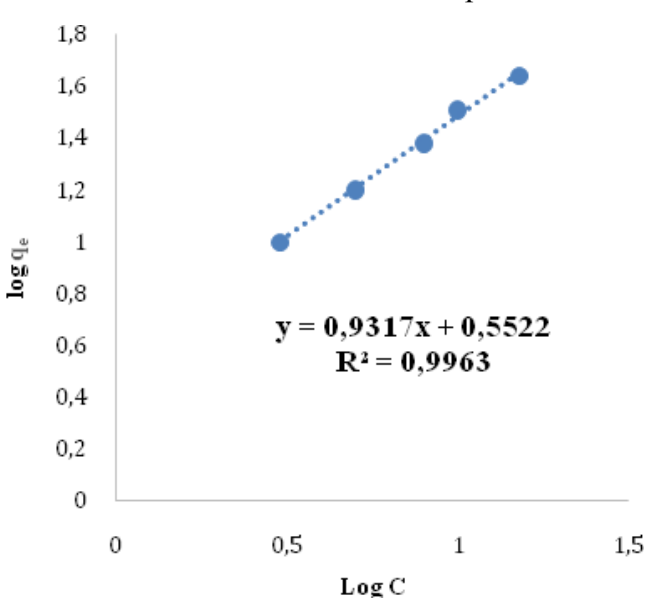

a)

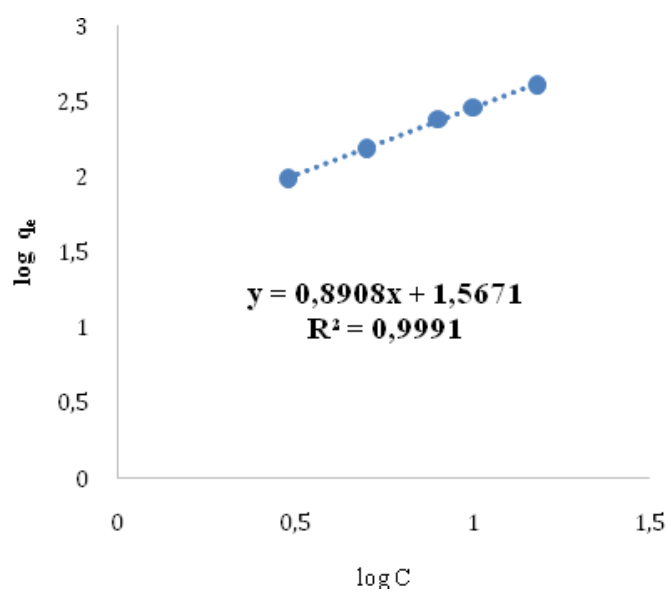

b)

Fig. 4. Freundlich adsorption isotherm for the $\mathrm{F}^{-}$ adsorption onto chitosan flakes (a) and $\mathrm{GDCLCB} / \mathrm{H}^{+}(\mathrm{b})$

Table 3

Langmuir constants $\left(q_{0}\right)$ for adsorption of $F^{-}$onto various types of chitosan-based adsorbents reported in the literature

\begin{tabular}{|l|c|c|}
\hline \multicolumn{1}{|c|}{ Adsorbent } & Maximum adsorption capacity, mg/kg & References \\
\hline Aluminium impregnated chitosan & 1731 & {$[45]$} \\
\hline Chitosan composite - nano hydroxyapatite & 2040 & {$[16]$} \\
\hline Carboxylate chitosan beads & 1111 & {$[46]$} \\
\hline Chitosan composite - hydrotalcite & 1876 & {$[26]$} \\
\hline GDCLCB/H+ & 2000 & Present study \\
\hline
\end{tabular}




\subsection{Field Study}

The analysed water quality parameters of the water samples collected from dug wells, wells, reverse osmosis plants, reservoirs of two homestead sites (site A and site
B, Fig. 14) of Kirigollewa G.N Division of Madawachchiya, NCP of Sri Lanka are tabulated in Table 4. The permissible levels defined for the selected parameters by the Sri Lanka Standards Institute (SLS 614:2013) in drinking water are given in Table 5.

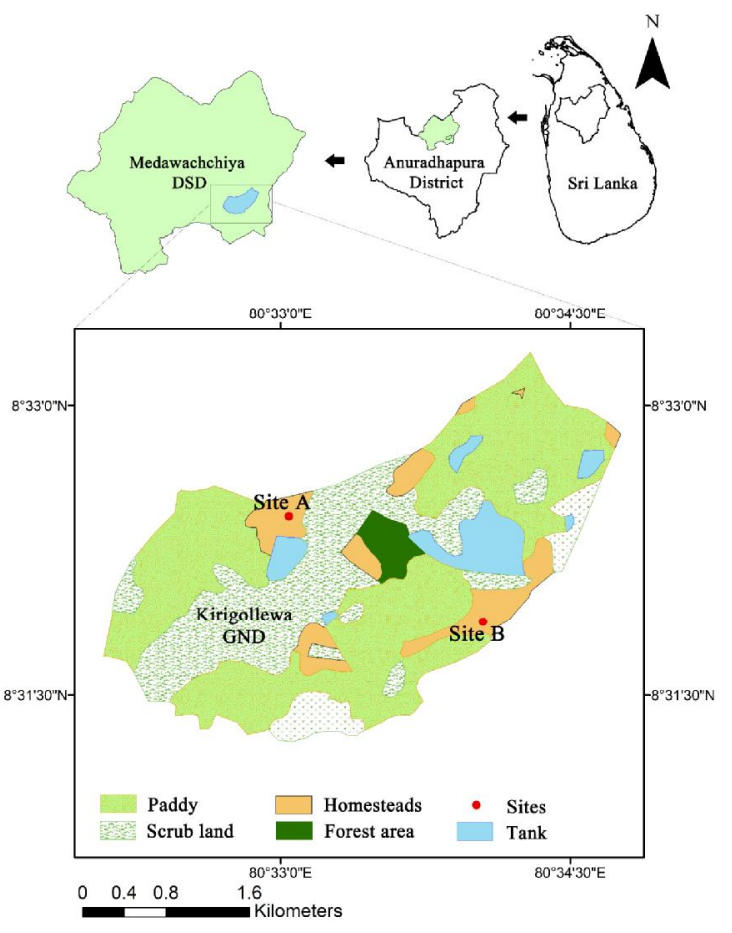

Fig. 5. Water sampling sites (Site A and Site B)

in Kirigollewa G. N. Division, Madawachchiya, NCP, Sri Lanka

Table 4

Results of basic water quality parameters in water samples collected in Kirigollewa area

\begin{tabular}{|c|c|c|c|c|c|c|c|}
\hline Sample & $\mathrm{pH}$ & $\begin{array}{c}\text { DO, } \\
\mathrm{mg} / \mathrm{l}\end{array}$ & $\begin{array}{c}\text { Conductivity, } \\
\mathrm{\mu S} / \mathrm{cm}\end{array}$ & $\begin{array}{c}\text { Salinity, } \\
\mathrm{ppt}\end{array}$ & $\begin{array}{c}\mathrm{TDS}, \\
\mathrm{mg} / 1\end{array}$ & $\begin{array}{c}\text { Hardness, } \\
\mathrm{mg} \mathrm{CaCO}_{3} / 1\end{array}$ & $\begin{array}{c}\text { Alkalinity, } \\
\mathrm{mg} \mathrm{CaCO}_{3} / 1\end{array}$ \\
\hline $\mathrm{Ki}_{\mathrm{a}} 1$ & 6.70 & 8.92 & 672.0 & 0.33 & 326.0 & $231.7 \pm 0.03$ & $40.0 \pm 0.00$ \\
\hline $\mathrm{Ki}_{\mathrm{a}} 2$ & $6.11^{*}$ & 8.12 & 561.0 & 0.26 & 271.0 & $381.4 \pm 0.03^{*}$ & $44.6 \pm 0.07$ \\
\hline $\mathrm{Ki}_{\mathrm{a}} 3$ & 6.75 & 9.07 & $1565.0^{*}$ & 0.79 & $778.0^{*}$ & $92 \pm 0.03$ & $33.8 \pm 0.04$ \\
\hline $\mathrm{Ki}_{\mathrm{a}} 4$ & $5.70^{*}$ & 7.12 & 79.9 & 0.04 & 37.4 & $136.5 \pm 0.07$ & $110.2 \pm 0.04$ \\
\hline $\mathrm{Ki}_{\mathrm{a}} 5$ & 6.69 & 7.56 & $809.0^{*}$ & 0.40 & $809.0^{*}$ & $325.3 \pm 0.07^{*}$ & $47.0 \pm 0.07$ \\
\hline $\mathrm{Ki}_{\mathrm{a}} 6$ & $6.09^{*}$ & $4.67^{*}$ & 484.0 & 0.23 & 234.0 & $312.3 \pm 0.07^{*}$ & $88.7 \pm 0.04$ \\
\hline $\mathrm{Ki}_{\mathrm{a}} 7$ & $6.35^{*}$ & 8.17 & 650.0 & 0.31 & 315.0 & $440.8 \pm 0.07^{*}$ & $25.8 \pm 0.00$ \\
\hline $\mathrm{Ki}_{\mathrm{a}} 8$ & 6.50 & 7.66 & 674.0 & 0.33 & 328.0 & $257.9 \pm 0.03^{*}$ & $48.9 \pm 0.07$ \\
\hline $\mathrm{Ki}_{\mathrm{a}} 9$ & $6.31^{*}$ & 7.43 & 664.0 & 0.32 & 323.0 & $352.9 \pm 0.14^{*}$ & $37.8 \pm 0.04$ \\
\hline $\mathrm{Ki}_{\mathrm{b}} 1$ & $6.49^{*}$ & 6.15 & $1038.0^{*}$ & 0.33 & $524.0^{*}$ & $126.8 \pm 0.21$ & $40.0 \pm 0.07$ \\
\hline $\mathrm{Ki}_{\mathrm{b}} 2$ & 7.50 & 5.82 & $961.0^{*}$ & 0.46 & 411.2 & $103 \pm 0.07$ & $127.6 \pm 0.04$ \\
\hline $\mathrm{Ki}_{\mathrm{b}} 3$ & 7.20 & 8.20 & 125.0 & 0.39 & 278.0 & $94.4 \pm 0.14$ & $48.6 \pm 0.07$ \\
\hline $\mathrm{Ki}_{b} 4$ & 7.09 & 5.11 & 508.0 & 0.24 & 245.6 & $128.0 \pm 0.07$ & $92.3 \pm 0.04$ \\
\hline $\mathrm{Ki}_{b} 5$ & 7.08 & 7.31 & 435.0 & 0.21 & 208.9 & $93.8 \pm 0.007$ & $58.3 \pm 0.04$ \\
\hline $\mathrm{Ki}_{\mathrm{b}} 6$ & 6.68 & $4.43^{*}$ & 151.4 & 0.07 & 71.8 & $132.7 \pm 0.07$ & $60.0 \pm 0.04$ \\
\hline $\mathrm{Ki}_{\mathrm{b}} 7$ & 6.98 & 7.31 & 522.0 & 0.22 & 245.0 & $324.9 \pm 0.00^{*}$ & $114.8 \pm 0.04$ \\
\hline $\mathrm{Ki}_{b} 8$ & 8.32 & 5.28 & 144.5 & 0.10 & 68.6 & $420.7 \pm 0.07^{*}$ & $33.8 \pm 0.00$ \\
\hline
\end{tabular}

Notes: $\mathrm{Ki}_{\mathrm{a}}=$ Kirigollewa $\mathrm{GN}$ division-site $\mathrm{A}, \mathrm{Ki}_{\mathrm{b}}=$ Kirigollewa $\mathrm{GN}$ division-site $\mathrm{B}$.

* The values which were not in the permissible range [47] 
SLS 614:2013 standards of drinking water [47]

\begin{tabular}{|c|c|c|c|c|c|}
\hline $\mathrm{pH}$ at $298 \pm 2 \mathrm{~K}$ & $\begin{array}{c}\text { Conductivity, } \\
\mu \mathrm{S} / \mathrm{cm}\end{array}$ & $\begin{array}{c}\mathrm{TDS}, \\
\mathrm{mg} / 1\end{array}$ & $\begin{array}{c}\text { Hardness, } \\
\mathrm{mg} \mathrm{CaCO}_{3} / 1\end{array}$ & $\begin{array}{c}\text { Alkalinity, } \\
\mathrm{mg} \mathrm{CaCO}_{3} / 1\end{array}$ & $\begin{array}{c}\mathrm{DO}, \\
\mathrm{mg} / 1\end{array}$ \\
\hline $6.5-8.5$ & 750 & 500 & 250 & 200 & $5.0-9.5$ \\
\hline
\end{tabular}

Table 6

$F$ concentration of water samples before and after treatment with the adsorbent GDCLCB/ $\mathrm{H}^{+}$.

\begin{tabular}{|c|c|c|}
\hline $\begin{array}{c}\text { Water } \\
\text { sample }\end{array}$ & $\begin{array}{c}\mathrm{F}^{*} \text { concentration before treatment with the } \\
\text { adsorbent, } \mathrm{mg} / \mathrm{l}\end{array}$ & $\begin{array}{c}\mathrm{F}^{*} \text { concentration after treatment with the adsorbent } \\
\text { GDCLCB/H }\end{array}$ \\
\hline $\mathrm{Ki}_{\mathrm{a}} 1$ & $1.4 \pm 0.05$ & $0.8 \pm 0.05$ \\
\hline $\mathrm{Ki}_{\mathrm{a}} 2$ & $1.3 \pm 0.10$ & $0.9 \pm 0.04$ \\
\hline $\mathrm{Ki}_{\mathrm{a}} 3$ & $0.6 \pm 0.05$ & $0.5 \pm 0.05$ \\
\hline $\mathrm{Ki}_{\mathrm{a}} 4$ & $2.8 \pm 0.03^{*}$ & $1.3 \pm 0.02$ \\
\hline $\mathrm{Ki}_{\mathrm{a}} 5$ & $1.2 \pm 0.05$ & $0.8 \pm 0.05$ \\
\hline $\mathrm{Ki}_{\mathrm{a}} 6$ & $3.3 \pm 0.04^{*}$ & $2.2 \pm 0.05^{*}$ \\
\hline $\mathrm{Ki}_{\mathrm{a}} 7$ & $0.6 \pm 0.05$ & $0.4 \pm 0.10$ \\
\hline $\mathrm{Ki}_{\mathrm{a}} 8$ & $1.7 \pm 0.02^{*}$ & $1.4 \pm 0.10$ \\
\hline $\mathrm{Ki}_{\mathrm{a}} 9$ & $3.2 \pm 0.05^{*}$ & $1.8 \pm 0.05^{*}$ \\
\hline $\mathrm{Ki}_{\mathrm{b}} 1$ & $1.2 \pm 0.05$ & $0.8 \pm 0.02$ \\
\hline $\mathrm{Ki}_{\mathrm{b}} 2$ & $1.0 \pm 0.07$ & $0.7 \pm 0.05$ \\
\hline $\mathrm{Ki}_{\mathrm{b}} 3$ & $0.7 \pm 0.05$ & $0.6 \pm 0.05$ \\
\hline $\mathrm{Ki}_{\mathrm{b}} 4$ & $1.0 \pm 0.04$ & $0.8 \pm 0.10$ \\
\hline $\mathrm{Ki}_{\mathrm{b}} 5$ & $2.2 \pm 0.10^{*}$ & $1.6 \pm 0.08^{*}$ \\
\hline $\mathrm{Ki}_{\mathrm{b}} 6$ & $1.4 \pm 0.05$ & $0.9 \pm 0.05$ \\
\hline $\mathrm{Ki}_{\mathrm{b}} 7$ & $1.2 \pm 0.10$ & $0.8 \pm 0.10$ \\
\hline $\mathrm{Ki}_{b} 8$ & $2.3 \pm 0.03^{*}$ & $1.2 \pm 0.05$ \\
\hline
\end{tabular}

Note: *Values which exceeded the permissible F level set by WHO [4]

The $\mathrm{pH}$ of the water samples collected was in the range of 5.70-8.32. According to the SLS guidelines for drinking water, the public water systems should maintain $\mathrm{pH}$ levels within the range of 6.5-8.5. $\mathrm{pH}$ of six water samples collected in Kirigollewa GN division was not within the permissible range. An adequate level of dissolved oxygen (DO) is necessary for good water quality as it provides oxygen for aquatic biota for respiration and aerobic decomposition of organic matter. Two samples among the collected samples had lower DO values (sample $\mathrm{Ki}_{\mathrm{a}} 6$ and $\mathrm{Ki}_{\mathrm{b}} 6$ ). One of the major causes of turbidity in drinking water is dissolved solids present in water. According to the World Health Organization (WHO), water with a total dissolved solids (TDS) level of less than $500 \mathrm{mg} / 1$ is generally considered to be good; drinking-water becomes significantly and increasingly unpalatable at TDS levels greater than $1000 \mathrm{mg} / \mathrm{l}$ [4]. For drinking water, the maximum permissible TDS level set by SLS and EPA is $500 \mathrm{mg} / 1$ [47, 48]. There were three water samples among the water samples collected with TDS levels greater than $500 \mathrm{mg} / \mathrm{l}$. According to the SLS standards the highest desirable level for total hardness of drinking water is $250 \mathrm{mg} / 1 \mathrm{CaCO}_{3}$. According to that, eight water samples have exceeded the permissible level of total water hardness. The concentration of $\mathrm{F}^{-}$in the collected water samples, $\mathrm{F}^{-}$concentration after treatment with $\mathrm{GDCLCB} / \mathrm{H}^{+}$are shown in Table 6. Maximum permissible level given by WHO and SLS 614:2013 guidelines for $\mathrm{F}^{-}$in drinking water is 1.5 and $1.0 \mathrm{mg} / \mathrm{l}$, respectively.

$\mathrm{F}^{-}$concentration of all the water samples were reduced by treating them with $\mathrm{GDCLCB} / \mathrm{H}^{+}$. Six water samples from Kirigollewa area had exceeded the permissible fluoride level $(1.5 \mathrm{mg} / \mathrm{l})$ as shown in Table 6 . As $\mathrm{F}^{-}$concentration of most of the collected water samples was successfully reduced to the permissible level by treating them with the adsorbent GDCLCB/ $\mathrm{H}^{+}$, it can be concluded that protonated cross-linked chitosan derivative, GDCLCB $/ \mathrm{H}^{+}$can be used as a cost-effective defluoridation agent for drinking water purification. It is also important to note that the presence of other metal ions and anions in the water may affect the Fremoval by the adsorbent, which could be studied further. 


\section{Conclusions}

This study shows that the DC of physically and chemically modified chitosan derivative, $\mathrm{GDCLCB} / \mathrm{H}^{+}$is higher than that of unmodified chitosan. It has also been found that the $\mathrm{DC}$ of $\mathrm{GDCLCB} / \mathrm{H}^{+}$depends on the initial $\mathrm{F}^{-}$concentration, adsorbent dosage, contact time and, $\mathrm{pH}$ of the solution. The optimal performance of GDCLCB $/ \mathrm{H}^{+}$ was observed at initial $\mathrm{F}^{-}$ion concentration of $15 \mathrm{mg} / \mathrm{l}$, adsorbent dosage of $0.6 \mathrm{~g}$, contact time of $30 \mathrm{~min}$ and $\mathrm{pH}$ of the solution in the range of 5-7. Adsorption equilibrium data of $\mathrm{F}^{-}$adsorption onto $\mathrm{GDCLCB} / \mathrm{H}^{+}$at $303 \pm 2 \mathrm{~K}$ under optimized conditions were well fitted to the Freundlich isotherm model and Langmuir isotherm model. Langmuir constant $\left(q_{0}\right)$ for adsorption of $\mathrm{F}^{-}$onto GDCLCB $/ \mathrm{H}^{+}$was found to be $2000 \mathrm{mg} / \mathrm{kg}$, which was significantly higher than that of unmodified chitosan flakes $(192.3 \mathrm{mg} / \mathrm{kg})$ and most of the chitosan-based sorbents previously reported in the literature. Further, the results obtained from field studies suggested that GDCLCB $/ \mathrm{H}^{+}$could be used as an efficient, environmentally friendly and cost-effective adsorbent for the defluoridation of water.

\section{Acknowledgments}

This work was supported by the University Grant Commission (grant number: RP/03/SR/02/06/01/2016), Sri Lanka.

\section{References}

[1] Dissanayake C.: J. Nat. Sci. Found. Sri Lanka, 2005, 33, 161. https://doi.org/10.4038/jnsfsr.v33i3.2322

[2] Firempong C., Nsiah K., Awunyo-Vitor D., Dongsogo J.: Ghana Med. J., 2013, 47, 16.

http://www.ncbi.nlm.nih.gov/pubmed/23661851\%0Ahttp://www.pu bmedcentral.nih.gov/articlerender.fcgi?artid=PMC3645181

[3] Habuda-Stanić M., Ravančić M., Flanagan A.: Materials, 2014, 7, 6317. https://doi.org/10.3390/ma7096317

[4] Gorchev H., Ozolins G.: WHO Chron., 1984, 38, 104.

[5] Kodama H., Kabay N.: Solid State Ionics, 2001, 141-142, 603. https://doi.org/10.1016/S0167-2738(01)00775-5

[6] Khatibikamal V, Torabian A, Janpoor F, Hoshyaripour G.: J. Hazard. Mater, 2010, 179, 276.

https://doi.org/10.1016/j.jhazmat.2010.02.089

[7] Turner B. et al.: Water Res., 2014, 33, 3395.

https://doi.org/10.1021/es0505090

[8] Meenakshi, Maheshwari R.: J. Hazard. Mater., 2006, 137, 456.

https://doi.org/10.1016/j.jhazmat.2006.02.024

[9] Sehn P.: Desalination, 2008, 223, 73.

https://doi.org/10.1016/j.desal.2007.02.077

[10] Bhatnagar A., Kumar E., Sillanpää M.: Chem. Eng. J., 2011, 171, 811. https://doi.org/10.1016/j.cej.2011.05.028

[11] Chakrabortty S., Roy M., Pal P.: Desalination, 2013, 313, 115. https://doi.org/10.1016/j.desal.2012.12.021
[12] Owa F.: Int. Lett. Nat. Sci., 2015, 8, 1.

https://doi.org/10.18052/www.scipress.com/ilns.8.1

[13] Alagumuthu G., Rajan M.: Hemijska Industrija, 2010, 64, 295.

https://doi.org/10.2298/hemind100307017a

[14] Malay DK, Attar S.: Res. J. Chem. Sci., 2011, 1, 68.

[15] Maliyekkal S., Shukla S., Philip L., Nambi I.: Chem. Eng. J.,

2008, 140, 183. https://doi.org/10.1016/j.cej.2007.09.049

[16] Sairam Sundaram C., Viswanathan N., Meenakshi S.: Biores.

Technol., 2008, 99, 8226.

https://doi.org/10.1016/j.biortech.2008.03.012

[17] Meenakshi S., Viswanathan N.: J Colloid Interface Sci., 2007,

308, 438. https://doi.org/10.1016/j.jcis.2006.12.032

[18] Alagumuthu G., Veeraputhiran V., Venkataraman R.: Hemijska Industrija, 2011, 65, 23.

https://doi.org/10.2298/HEMIND100712052A

[19] Yadav A., Kaushik C., Haritash A. et al.: J. Hazard. Mater.,

2006, 128, 289. https://doi.org/10.1016/j.jhazmat.2005.08.006

[20] Malakootian M., Moosazadeh M., Yousefi N., Fatehizadeh, A.:

African J. Environ. Sci. Technol., 2011, 5, 299.

https://doi.org/10.5897/AJEST10.308

[21] Chidambaram S., Ramanathan A., Vasudevan S.: Water SA,

2003, 29, 339. http://dx.doi.org/10.4314/wsa.v29i3.4936

[22] Vardhan C., Karthikeyan J.: Fifteenth International Water

Technology Conference, IWTC-15 2011, Alexandria, Egypt, 2011, $\mathrm{I}(2), 1$.

[23] Chen N., Zhang Z., Feng C. et al.: Mater. Chem. Phys., 2011,

125, 293. https://doi.org/10.1016/j.matchemphys.2010.09.037

[24] Shams M., Nodehi R., Dehghani M. et al.: Fluoride, 2010, 43, 61. http://www.fluorideresearch.org/431/fluoride

[25] Mohapatra M., Anand S., Mishra B. et al.: J. Environ. Manage., 2009, 91, 67. https://doi.org/10.1016/j.jenvman.2009.08.015

[26] Viswanathan N., Meenakshi S.: Appl. Clay Sci., 2010, 48, 607. https://doi.org/10.1016/j.clay.2010.03.012

[27] Assaad E., Azzouz A., Nistor D. et al.: Appl. Clay Sci., 2017, 37, 258. https://doi.org/10.1016/j.clay.2007.02.007

[28] Mishra D., Tripathy J., Srivastava A. et al.: Carbohyd. Polym., 2008, 74, 632. https://doi.org/10.1016/j.carbpol.2008.04.015

[29] Reddy D., Lee S.: Adv. Colloid Interface Sci., 2013, 201-202, 68. https://doi.org/10.1016/j.cis.2013.10.002

[30] Muzzarelli R.., Weckx M., Filippini O., Sigon F.: Carbohyd. Polym., 1989, 11, 293. https://doi.org/10.1016/0144-

8617(89)90004-0

[31] Liu X., Zhang L.: Powder Technol., 2015, 277, 112.

https://doi.org/10.1016/j.powtec.2015.02.055

[32] Rajeswari A., Amalraj A., Pius A.: J. Environ. Chem. Eng.,

2015, 3, 2331. https://doi.org/10.1016/j.jece.2015.08.022

[33] Bozorgpour F., Ramandi H., Jafari P. et al.: Int. J. Biol.

Macromol, 2016, 93, 557.

https://doi.org/10.1016/j.ijbiomac.2016.09.015

[34] Menkouchi Sahli M., Annouar S., Tahaikt M. et al.:

Desalination, 2007, 212, 37.

https://doi.org/10.1016/j.desal.2006.09.018

[35] Kamble S., Jagtap S., Labhsetwar N. et al.:Chem. Eng. J.,

2007, 129, 173. https://doi.org/10.1016/j.cej.2006.10.032

[36] Jagtap S., Yenkie M., Labhsetwar N., Rayalu S.: Micropor.

Mesopor. Mat., 2011,142, 454.

https://doi.org/10.1016/j.micromeso.2010.12.028

[37] Viswanathan N., Sundaram C., Meenakshi S.: J. Hazard.

Mater., 2009 ,161, 423.

https://doi.org/10.1016/j.jhazmat.2008.03.115 
[38] Queiroz M., Melo K., Sabry D. et al.: Marine Drugs, 2015, 13, 141. https://doi.org/10.3390/md13010141

[39] Lim S., Hudson S.: Carbohyd. Res., 2004, 339, 313. https://doi.org/10.1016/j.carres.2003.10.024

[40] Patnaik S., Mishra P., Nayak R., Giri A.: J. Anal. Bioanal. Tech., 2016, 7, 326. https://doi.org/10.4172/2155-9872.1000326 [41] Rajapakse C., Martínez A., Naoulou B. et al.: Inorg. Chem., 2009, 48, 1122. https://doi.org/10.1021/ic802220w

[42] Viswanathan N., Meenakshi S.: J. Colloid Interf. Sci., 2008, 322, 375. https://doi.org/10.1016/j.jcis.2008.03.007

[43] Swenson H., Stadie N.: Langmuir, 2019, 35, 5409. https://doi.org/10.1021/acs.langmuir.9b00154

[44] Saadi R., Saadi Z., Fazaeli R., Fard N.: Korean J. Chem. Eng., 2015, 32, 787. https://doi.org/10.1007/s11814-015-0053-7

[45] Swain S., Dey R., Islam M. et al.: Separ. Sci. Technol., 2009, 44, 2096. https://doi.org/10.1080/01496390902881212

[46] Viswanathan N., Sundaram C. S., Meenakshi S.: Colloid Surface B, 2009, 68, 48.

https://doi.org/10.1016/j.colsurfb.2008.09.009

[47] Sri Lanka Standards for potable water - SLS 614: 2013. https://www.slsi.lk/images/downloads/other/accredited_tests_1.pdf [48] Pontius F.: J. Am. Water Works Assoc., 2003, 95, 57. https://doi.org/10.1002/j.1551-8833.2003.tb10314.x

Received: November 26, 2019 / Revised: January 15, 2020 / Accepted: March 12, 2020

\section{ВИДАЛЕННЯ ФЛУОРУ 3 ПИТНОЇ ВОДИ З ВИКОРИСТАННЯМ ПРОТОНОВАНИХ ХІТОЗАНОВИХ КУЛЬОК ЗШИТИХ ДИГЛІЦИДИЛОВИМ ЕТЕРОМ}

Анотація. Одержано фізично та хімічно модифікований хітозан та протоновані хітозанові кульки зшиті дигліцициловим етером $\left(G D C L C B / H^{+}\right)$. Характеристику продуктів отримано за допомогою Фур'є-спектроскопії та скануючоі електронної мікроскопії. Встановлено, що оптимальна дефлуоруюча здатність $\mathrm{GDCLCB} / \mathrm{H}^{+}$спостерігається за початкової кониентрації йонів флуору $15 \mathrm{mz/л,} \mathrm{дозі} \mathrm{адсорбенту} \mathrm{0,6} \mathrm{2,} \mathrm{часі}$ 30 хв і рН розчину в межах 5-7 за температури $303 \pm 2 \mathrm{~K}$. Показано, щзо результати рівноважної адсорбиї добре узгоджуються з моделями ізотерми Ленгмюра та Фрейндліха. 3 ізотерми Ленгмюра для $F$ адсорбиії визначено максимальну адсорбиійну здатність, 2000 мг/кг, щуо $\epsilon$ значно вищою величиною, ніж для немодифікованого хітозану (192,3 мг/кг) та більшості сорбентів на основі хітозану, відомих з літератури. На прикладі зразків води, відібраних в одній з провінцій Шрі-Ланка, показано, що $G D C L C B / H^{+}$можна використовувати як ефективний засіб для дефлуорування.

Ключові слова: дефлуоруюча здатність, флуор, $G D C L C B / H^{+}$. 